\title{
Introduction: The Karamazov Correspondence
}

$\mathrm{T}^{\mathrm{t}}$ is commonly believed that Fyodor Dostoevsky modeled his fictional - character Alyosha — the novitiate monk in the novel Brothers Karamazov—on his young friend, the budding religious philosopher Vladimir Sergeevich Soloviev (1853-1900). However, Dostoevsky's wife, Anna, believed that the young Soloviev provided greater inspiration for her husband's fashioning of the middle Karamazov-the intellectual Ivan. Moreover, it has been suggested that Soloviev also influenced the depiction of the intemperate elder sibling, Dmitri, which, when added to the other two portrayals, yields a kind of literary triptych. ${ }^{1}$

Facets of this Karamazov triptych - the otherworldly Christ-likeness of Alyosha, the rationalism of Ivan, and the intemperate nature of Dmitriare also displayed in the real-life Soloviev's personal letters, which contribute enormously to understanding this complex figure, who was so crucial to late nineteenth-century Russian intellectual and literary discourse.

Soloviev's correspondence with family, friends, and contemporary notables, as well as with his readers more generally, eventually filled more than four published volumes, which provide an intimate supplement to the ten volumes that comprise his other writings. ${ }^{2}$ For it is in these letters that we find Soloviev's deepest thoughts, impressions, and feelings on myriad subjects that would have been considered revelatory-and in some instances even shocking — while he lived: these include aspects of his love life; the serious and multifaceted health problems that he faced; his day-to-day worries about money and debts; and his sometimes rather explicit and coarse comments about the luminaries he knew. All this appeared against the backdrop of his overarching concerns-the religious, social, and political problems of his day. Most, if not all, of the seeds of the writings for which he is better known may be found in these letters.

After a youthful infatuation with nihilism, Vladimir Soloviev, the son of the eminent historian Sergei Mikhailovich Soloviev, sensed a calling to a destiny 
greater than following in his father's footsteps or occupying a comfortable niche in the imperial Russian bureaucracy. Indeed, he would eventually forsake many conventional norms considered more or less standard for someone of his class and intellectual prowess in Russian society - married life, a university post, and a sinecure in that bureaucracy - in favor of the twofold mission of change to which he understood himself being called: serving Christ and Christianity in the task of ecumenism and unity, and evangelizing to Russia's elites about their obligations to the world in this regard.

So it was at the age of twenty that Soloviev first began to elucidate this calling in a series of distinctly evangelistic letters to his then-fiancée Katya, at about the same time that he started to outline the contours of a portion of that lifelong mission: bringing to light what he referred to as the "absolute unity" of Divinity. That notion would later translate into the idea of "all-unity" (vseedinstvo), Soloviev's signature term for Divinity's penetration and unification of all reality through the God-man Jesus Christ.

Soloviev's youthful letters to his fiancée echo many of Jesus's imperatives to his disciples, such as that their lives should be dedicated not to reclusive contemplation but to active participation in change: "At one time, monastic life had its high appointment, but now the time has come not to run from the world but to go into the world, and to go into the world in order to transform it." Other letters to friends and family also disclose a great deal about that purpose and just how he thought about achieving it, as well the successes and failures he encountered along the way.

The letters in the present volume confirm, with considerable power, the scope and significance of Soloviev's contributions to ecumenical discourse and unity, which have long been appreciated as crucial in the Orthodox East but less so in the West. For a long while, Vladimir Soloviev was recognized in the West primarily for a few of his philosophical writings and his posthumous influence on the so-called second generation of Russian Symbolist writers (Andrei Bely, Alexander Blok, Vyacheslav Ivanov). The Russian Academy of Sciences more fully acknowledged his activity as transcending intellectual or artistic boundaries, accepting him into its ranks in the triple capacity of philosopher, social and political commentator, and poet. ${ }^{3}$ And so it is significant that on the centenary of his death, the Vatican officially praised him as a "Russian figure of extraordinary depth, who also noted with great clarity the tragic division among Christians and the great urgent need for their unity."

For the first time, readers of Soloviev in English may now follow the evolution of his thought through his correspondence, as he cultivated the germs of 
ideas into the final versions of works such as The History and Future of Theocracy, Russia and the Universal Church, and The Meaning of Love. They can also view facets of his humanness that have been otherwise eclipsed by his prowess and activity as a public intellectual — things he held in common with all who have ever walked the earth, ranging from times of carefree happiness and enjoying simple pleasures to others of interpersonal tensions and grief, jealousy as well as anger. They will also become privy to interludes of profound loneliness, when he craved company but had none, and to times of deep sorrow, when one or another of his friends or acquaintances passed away. And they will also find glimpses of a much lighter side, in perorations on a night of imbibing too much wine or in humorous reflections on the absurdities of life and his own mortality, which seems to have been a constant companion for him, considering his frailties and the chronic, often debilitating, illnesses that plagued him from cradle to grave.

Soloviev explored all sorts of traditional and nontraditional remedies and therapies for the various maladies that seemed to afflict him without respite: it was even rumored that he regularly drank turpentine as a therapeutic as well as using it externally as a disinfectant. ${ }^{5}$ In any event, his letters relate-at times in excruciating detail-the extent to which illnesses of all kinds impeded his ability to work over the course of his adult life. ${ }^{6}$

\section{MASTER OF LANGUAGE AND STYLE}

Soloviev's failure to meet writing deadlines because of one or another of his infirmities or ailments may have contributed to some friction with editors, but his habitual tardiness with personal correspondence was more likely due to a self-professed "laziness" to respond, which even bordered on a loathing that he once referred to as "epistolary phobia"-somewhat surprising, especially given the sheer number as well as the length of many of his letters.

Although he composed the vast bulk of his correspondence in Russian, Soloviev also produced a number of letters in French, and at least one-a humorous note-has survived in passable English. Perhaps more purposefully than most others around him, he regularly laced his writing with smatterings of other languages too, ancient as well as modern; so we find phrases in Hebrew, Church Slavonic, Greek, Latin, German, and Italian throughout his correspondence as well as in his professional work. And as is evident in other letters, he even toyed with Croatian and Swedish (the latter in a platonic interlude with a chambermaid on one of his Nordic excursions). 
xii | Introduction: The Karamazov Correspondence

Soloviev's love of languages may have inspired him to flirt with one or another of them at different times, but his heart would always belong to Russian. The purity of this love was discerned early on, long before it had fully matured, and even by some who seemed instantly critical of the young upstart of a philosopher-in-the-making.

After the renowned Slavophile and critic Nikolai N. Strakhov read through Soloviev's master's thesis (“The Crisis of Western Philosophy: Against Positivism," 1874), he penned his impressions in a letter to his friend, the novelist Lev Tolstoy:

I share your opinion about Soloviev; although he manifestly disclaims Hegel, he secretly follows him. The entire criticism of Schopenhauer is based on this. But it seems it's even worse. After rejoicing that he's found the metaphysical essence, Soloviev's now ready to see it everywhere, face to face, and he's disposed to a faith in spiritism. Moreover, he's awfully sickly, as if emaciated-one should fear for him-he won't end well. But his booklet, the more I read it, the more talented it seems to me. What mastery of language, what communication, what force! (1875). ${ }^{7}$

Kudos similar to those at the end of Strakhov's comment may also be applied to Soloviev's letters, if not altogether evenly. For, as an eloquent artist of the word in both prose and poetry, he would often create artful and witty gems in his correspondence as well.

Although only a shadow of Soloviev the master stylist can be achieved in translation, I have indicated the contours of his epistolary style and tone in various ways, while unburdening the reader from arcane terms of theological and philosophical discourse or the tedious formalities that reflect the stiffness of the Victorian Age in which he lived. Readers of these letters can follow the development of Soloviev's tone and style from that of a young person searching for a voice and purpose to a mature, conscientious man of faith becoming more and more convinced of his mission, at the same time playfully exploiting the myriad and confounding absurdities of "life on this planet," as he referred to it more than once.

Soloviev's inclination to playfulness with language expanded as he aged, often defying his subject matter and even running counter to his mood at the moment. And this inclination grew in tandem with a conscious turn to humorous verses (shutochnye stikhi), his letters eventually becoming littered with wry allusions and punning of all kinds, including double entendre and interlingual 
word play that challenge modern readers, even in Russian. Witty versification and erudite punning certainly pleased some of his correspondents, while just as certainly alienating others. In any event, the literary quality of his wordplay more often impresses than disappoints. Take, for instance, the tongue-in-cheek "Epitaph" that the poet-philosopher provided for his own tombstone, some eight years before he died:

Vladimir Soloviev lies in this place;

A philosopher first, now a skeleton's face.

'Twas many that held him truly dear,

For others an enemy he was to fear;

But too passionate and lost in love,

He cast himself from high above.

A soul too lean, body no fatter:

Devil took the former, dogs ate the latter.

Passerby! Learn well from this instance,

Love's ruinous, and faith-good in persistence. ${ }^{8}$

\section{HAZARDOUS DISCOURSE}

Soloviev's self-deprecating humor may have amused many, but he no doubt jested a bit too much with respect to others, at times pushing the boundaries of propriety. It is quite telling that Ernest L. Radlov, the original editor of Soloviev's letters, found it necessary in his introductory comments to the first volume to deflect any potential hard feelings over the "gentle jests and mocking" contained therein. Radlov simply ascribed this jesting and mocking to a divinely inspired "purely childlike mirth." On this point he quoted the Croatian Catholic bishop Josip G. Strossmayer, who defended Soloviev as being "an honest soul, pious and truly holy."

However, the tendency to mock and jest seemed to present a problem for readers of Soloviev's published letters, as can be inferred from the fact that Radlov felt obliged to continue with this line of explanation in his introduction to the second volume, where he suggested that "moral inspiration" somehow trumped places of "indelicacy and even vulgarity." And with regard to the "hazardous comments" that sometimes made their way into Soloviev's letters, Radlov asserted: "One ought not to look for a hostile attitude or desire to condemn anybody—it's usually just a witty joke, a play of the mind—and nothing more." 
If some did find discourse with Soloviev to be hazardous, it was probably because of his deftness and acuity in crowning a bluntly honest observation with a brilliant jest that hit too close to the mark. To be sure, and as his letters clearly show, the philosopher-poet always seemed prepared to take the initiative to reconcile with anyone who may have taken umbrage at his witty and at times crude critiques either from his pen or face-to-face, not to speak of polemics on the printed page. And so claims of innocent banter could not always suffice as a defense, especially when "moral inspiration" challenged the intellectual and moral essence of renowned public figures such as Lev Tolstoy or Nikolai Strakhov.

As these letters detail, after many disagreements and tension-filled verbal battles, Soloviev's relationship with Strakhov gradually changed, the elderly materialistically inclined thinker eventually shunning the theologian-philosopher, who would end up referring to Strakhov as his "enemy-friend" (vragodrug), a neologism that nevertheless seemed to hold out hope, however faint, for reconciliation. And so, when the aged Strakhov fell mortally ill, Soloviev discreetly inquired about his enemy-friend and continued to seek reconciliation, but to no avail.

The Soloviev-Tolstoy relationship may have been just as tumultuous, but it did not end in bitterness. Soloviev seemed to be more of an irritating gadfly to Tolstoy, who commented privately in 1884 that he found the young philosopher "tedious and pitiable," but later admitted, if only to himself, that he did not feel comfortable around him: "Spoke with [Soloviev], not easily. I am somehow exceptionally cautious with him. Don't know why." ${ }^{10}$ One reason for that caution is suggested by an incident in which, after the appearance of Tolstoy's heretical "Brief Exposition of the Gospel" (1881), Soloviev-the-evangelist criticized him to his face — as well as in letters and on the printed page — regarding the liberties that the novelist-moralist had taken with the Christian Gospels. For Soloviev, this "pseudo-Christianity" may have been no different from other attempts over the ages to add or delete something from Christianity as put forward in the Nicene Creed, yet he would not let the matter drop, even referring once to Tolstoy's views as "semi-Buddhism" and at another time to Tolstoy himself as "our indispensable Columbus of all the discovered Americas."

Even so, Soloviev defended Tolstoy's right to say and write what he wanted in defiance of the official censorship, although he did not stop trying to convince him both directly and indirectly. It was in a long letter to Tolstoy that Soloviev produced one of the most eloquent and logically consistent Christian apologias on the topic of resurrection as a kind of ultimate reconciliation, with biological 
evolution serving as a backdrop for the mystery. With Christ as a model, he summarized it thus:

\begin{abstract}
Victory over death is the unavoidable natural consequence of intrinsic spiritual perfection; a person in whom the spiritual principle has taken away the power over everything lower, decisively and finally, cannot be subdued by death; spiritual power, having achieved the fullness of perfection, inevitably overflows, so to speak, over the edge of subjective-psychic life; it seizes corporeal life as well, transforms it, and then finally inspirits it, indissolubly tying it to itself.
\end{abstract}

\title{
IN QUEST OF DIVINE WISDOM, FOR LOVE OF SOPHIA
}

Soloviev's lifelong quest for mystical knowledge always seemed to lead back to scripture, where his frame of reference and mainstay would remain the eternal call of "wisdom" (Gk. "Sophia"), which resonates especially powerfully in the Hebrew Bible: "Does not wisdom call out? Does not understanding raise her voice? On the heights along the way, where the paths meet, she takes her stand; beside the gates leading into the city, at the entrances, she cries aloud: 'To you, O men, I call out; I raise my voice to all mankind"” (Proverbs 8:1-4). As a religious philosopher, the youthful Soloviev would find room in the Wisdom tradition for the idea of Divine Humanity (or Godmanhood-bogochelovechestvo), while at the same time attempting to preserve within it the idea of "the eternal feminine." 11

Not only do Soloviev's love letters to his cousin Katya provide glimpses of a romantic nature - at times tender, at times cross, and at others even jealousbut it is in them that we also first encounter the subtlety-perhaps even the sublimity - of Soloviev's quest for Divine Wisdom, as embedded in his Christian faith. And this appears almost coincidentally with an idealized spousal vision that could never have been ultimately realized in this life, but which may help shed some light on E. L. Radlov's curiously brief and enigmatic observation that "Soloviev attached importance to these letters, and asked whether they were intact."

The fact that Soloviev could not give first place in his heart either to Katya or to anything else that could interfere with his primary mission in quest of the Wisdom found in Christ undoubtedly contributed to the end of their relationship. He wrote to her: 
\begin{tabular}{l|l} 
xvi & Introduction: The Karamazov Correspondence
\end{tabular}

For the majority of people, the whole thing ends with this; love and what should follow: family happiness - constituting the major interest of their life. But I have a completely different mission, which becomes more clear, definite, and fixed for me each day. I will dedicate my life to its fulfillment, within my powers. Therefore, personal and family relations will always occupy second place in my being. And this is all I wanted to say when I wrote that I can't give all of myself to you.

As it happened, Soloviev would never be done with Wisdom — that is, Sophiaeither as an ideal or in practical reality.

As Soloviev's early letters reveal, after the breakup with his cousin, his quest for Wisdom led him to various excursions into the occult- that is, "Spiritualism" and "Spiritism," both in vogue at the time-even conducting him to destinations as far off as the British Museum and the Egyptian desert, most of which turned out to be disappointing in one way or another. But it was not all for naught, for Soloviev's philosopher friend Dmitri N. Tsertelev, who joined him at times in that quest, played a key role in his next serious encounters with femininity, acquainting him with two of his relatives, both of whom happened to be named-Sophia: Countess Sophia A. Tolstoy, widow of the poet Alexei K. Tolstoy, and her married but estranged niece, Sophia P. Khitrovo. ${ }^{12}$ The countess would hold seances at one of her residences, and Soloviev would participate, clinging to hope that a form of wisdom might be found therein, until he began to have unwholesome, even frightening visions and premonitions related to these experiences with the occult. Yet he had other reasons to frequent Krasny Rog and Pustynka - the Tolstoy estates - for a romantic relationship had blossomed between him and Sophia P., who lived with the countess. He would eventually end up spending long weeks, even many months, at one or the other, from time to time corresponding to friends and family about both Sophias.

Unfortunately, apart from a few poems and remarks, no letters to Sophia P. seem to have survived, but a number of Soloviev's letters addressed to Sophia A. have, and these are replete with sentiments and comments about "love." When taken together with remarks appearing in various other letters over the years, the tenor of these letters to the elderly Sophia could be interpreted as reflecting his involvement with the younger Sophia.

Soloviev would later maintain that he had remained chaste all his life, indirectly suggesting that this and every other romantic relationship of his had never exceeded religious or public norms of propriety. And though a few surviving letters to another married (but in this case younger) Sophia-Sophia 
M. Martynova - may be read as intimating something more, his involvement with women has generally remained enigmatic.

Sophia M. enthralled as well as vexed him over the years 1892-1895, a span that has been referred to as his "erotic" period. Any questions about Soloviev's chastity during that time must be placed in the larger context of a masterful series of essays that he was working on as his health declined. Appearing under the collective title "The Meaning of Love" (Smysl liubvi), these essays on the subject of sexual union seem to move back and forth from an aloof and distinctly analytic tone to one strangely wry and playful. This back-and-forth, from analysis to playfulness, may be attributed at least in part to Soloviev's overall purpose - to cast light on the fundamental nature of the universe as the "all-unity" idea, only imperfectly realized in clumsy, corporeal reality. Taken together with his essays on sex and cosmic all-unity, Soloviev's love letters seem to hold two interdependent principles as central: Wisdom may be found in the mystery of eternal Divine Femininity as the source of potential regeneration for all humankind, while a mercurial, if inept, syzygy (Gk. a conjunction or combination of forces) supplies necessary signposts toward that telos.

Famously conceived and written near Lake Saimaa in Finland, Soloviev's serious poetry during this time suggests the fading of an idyllic dream, and perhaps even a descending fatalistic mood, which might be understood as implying an internal struggle between that dream, or mood, and Wisdom. Among various verses carrying that sense in his letters to Sophia $M$, the following four lines stand out:

When my daydream at the edge of previous days

Finds you somewhere back there in a foggy haze,

I'll cry sweetly, just like the first Jew

At the brink of the Promised Land.

But the inspiration that Soloviev's muse provided came at a price, for it brought along unexpected practical headaches and costs, such that he would remark to his younger brother Misha about Sophia M.: "Imagine, I have to deal with such a disposition, compared to which S. P. [Sophia Petrovna] is simplicity and ease themselves."

\section{JUST BUSINESS: PUBLISH OR PERISH, "SEND IT REGISTERED”}

Soloviev's letters also offer rare insights into more mundane aspects of his life, including the business of publishing in Russia-all the processes involved 
in reviewing, editing, and distributing books, pamphlets, and reprints at a time when the system of censorship was still in place, though weakening. Some of them also provide a peek at motivations from the other end-the unofficial infrastructures of dependency, personal favors, financial support and patronage, without which Soloviev could not have produced all that he eventually did.

And little of this had anything at all to do with Soloviev's abbreviated career as a professor, teaching courses on idealism and the history of philosophy. That career ended in the wake of his public stance against the death penalty for Tsar Alexander II's assassins (March 1881). In truth, Soloviev did not take to teaching or to the role of professor at all. After resigning his teaching position and his "sinecure"-as collegiate adviser to the Academic Committee at the Ministry of Public Education - he had to reinvent himself rather quickly in order to support himself through writing. There is little indication in his correspondence that he ever regretted these decisions; and later he even spoke with disdain about "the duties of a teacher" and curtly rejected the "title of professor" when it was used to identify him to the public.

With no steady stream of income, financial concerns forced Soloviev to bear down and deal directly with the business end of writing, a raw fact of life that we sometimes find spilling over into other places in his correspondence, as well as his professional writing. The imperative to "publish or perish"-so familiar to the modern university professorate-applies almost literally to Soloviev's predicament. Irregular royalties and "honoraria," along with occasional assistance from his mother and siblings and some royalty income from his late father's work, could not prevent this generous almsgiver from regularly finding himself in desperate financial circumstances; and the situation was never permanently ameliorated, even with his appointment in 1891 as editor of the philosophical section for the most important reference work of his day, the Brokhaus-Efron Encyclopedic Dictionary (Entsiklopedicheskii slovar' F. A. Brokgauza i I. A. Efrona [1890-1907]).

The amount of time and energy Soloviev invested in the day-to-day business of publishing may come as a surprise to many. Correspondence with various patrons, publishers, and editors, as well as his own devoted readers, constitutes a substantial portion of the original volumes of letters. Page proofs, contracts, advances - all had to be forwarded and received quickly, seemingly in a never-ending stream. Yet the sometimes frantic tone audible in all this just as quickly dissipated in patient, sympathetic personal responses to his readers, relative strangers who would inquire about this or that aspect of faith and life, 
or in one case even distress him with misguided rants (i.e., the self-professed mystic Anna Schmidt, who fantasized herself as his soul mate).

It is difficult to see how Soloviev could have accomplished all the business of publishing — marketing and distribution, receipt of payments, and so onwithout the assistance of his younger and "favorite" brother Misha, who often acted both as his agent and his business partner. The letters to his brother are among the most enjoyable and informative to read, for Misha not only worked in these capacities but also remained his famous elder brother's most trusted adviser and confidant.

Lack of a steady income contributed to the reality of Soloviev's stressful life, which he himself understood as not unlike that of a restless wanderer, amounting to a "nomadic" existence that at times bordered on vagrancy. But this wanderer on the brink of vagrancy would also be saved from complete destitution by family and friends. He spent time with family, of course, but also became the guest of their friends as well as his own, paying extended visits to homes and estates throughout Russia and abroad. Favorite retreats included his mother's Prechistenka residence in Moscow; Lipyagi, the residence of his friend Dmitri Tsertelev; Vorobievka, the estate of the poet Afanasy A. Fet; as well as Krasny Rog and Pustynka, Countess Sophia A. Tolstoy's estates. And when a boon of royalties arrived, he would manage to go abroad to recuperate, rest, and finish important projects - spending a month, sometimes more, here or there, at the French writer Leroy-Beaulieu's country cottage outside Versailles or on the Riviera near Nice. He would, of course, still conduct business from these and other retreats-by post.

But the Russian imperial postal service all too often failed to meet even the most basic expectation of safe and timely delivery of letters and packages to their destinations. As Soloviev once wrote to his Jesuit friend and informal editor Father Pavel Pierling, "the Russian post does not live under law, but under grace." Alternate means of conveyance were a necessity for Soloviev and others of his intellectual and social class; communications would quite commonly be delivered by private messenger, occasional courier, and friends and acquaintancesthe last especially for those containing "sensitive" material. Such means were not only meant to speed up transit or guarantee same-day delivery but also to assure that serious and lasting consequences would not result from a failure to take precautions with mail, either sent within Russia or from abroad.

In fact, the more Soloviev challenged church and state authorities through his public activities and in print-for example, "correcting" the former on dogma, questioning the latter on minority rights - the more his mail seemed to experience "problems" with privacy, security, and/or timely delivery. 
xx $\quad$ Introduction: The Karamazov Correspondence

Something more than just the standard incompetence of a prying and blundering bureaucracy immediately came under suspicion when a letter or book sent by post arrived with evidence of tampering or did not reach its destination at all. Soloviev began to harbor somber concerns about the interception of his mail early on, even when it was sent "registered," a designation that ostensibly insured secure dispatch and arrival. The situation would remain highly problematic, his correspondence eventually peppered almost continually with commentary on the deficiencies of the postal service. It is with characteristic wit and eloquence that Soloviev concluded one of his letters in 1895 with the following request for a response from its addressee, V. V. Rozanov:

Send it registered. Disdain for the institution of registered letters is incompatible either with providential humility or with respect for state authority. If Providence has repeatedly manifested examples of postal faultiness for us, evidently it's so that we take precautionary measures accessible to us, not troubling higher powers with a demand for supernatural help. On the other hand, if government wisdom has established and supports the institute of registered letters, this means it's essential, and since cases of its application are not indicated in law, this means we must consider it essential in all cases. In general, the difference that exists between humble and proud people is that the former dispatch registered letters, and the latter dispatch letters that don't reach their destination.

Suffice it to say that the writer of these words would have been greatly amused by the fact that a brief note he sent to his friend E. L. Radlov in 1900 was only received months after his own death.

\section{RELIGION AND POLITICS: HUMAN RIGHTS AND THE CONSCIENCE OF LIBERALISM}

The greatest jeopardy for Soloviev lay in the justice-infused Christian utopianism that he publicly propagated, directly challenging the collectivistic and individualist materialist philosophies of his day, on the one hand, and the church and state bureaucracies, on the other.

Beginning with his doctoral thesis, Soloviev would argue in different ways that "true community" was "indissolubly linked with true individualism." Popular materialist philosophies in particular appeared to him to work on the assumption that religion, morality, church, and state all amounted to mere 
"props" and/or "defensive instruments of the existing economic order," which could hardly qualify as promoting either human dignity and freedom or morality. ${ }^{13}$ Just as elsewhere in his writing, in his letters Soloviev drew a close connection between what he would later refer to as "true religion and sensible politics," a position that emerged organically from his understanding of the Bible, especially the New Testament on the subject of reconciliation. He never stopped considering it his "duty" to explain Christianity as "the idea of the Kingdom of God as the fullness of human life, not only individual but also social and political, reunited through Christ with the fullness of Divinity." ${ }^{14}$

While taking to task all European culture for abandoning Christian teaching, Soloviev directed the brunt of his critique at Russia and Eastern Orthodoxy. He understood Christian faith as both social and political vocation that incorporated the pursuit of justice, while rejecting all rationales for religiousand ethnic-based persecution and retribution of any kind. Along these lines, he openly championed full and equal legal rights for the Russian Empire's minorities (including schismatics). Just as in his essays and books, he took every opportunity in his letters to clarify how and why power relationships mattered in human rights and in church-state relations, as well as in social norms more generally; as a result, he became isolated from most social and political institutions, as well as much of the clerical establishment, with serious material consequences for his ability to earn a living in Russia through his writing.

Soloviev would show particular concern for the plight of Jews and Judaism and the treatment of Catholics and Catholicism. First, however, he had to break away from his ties to Slavophilism and its ideology. The gradual process of breaking off completely may have had its start when he went off to war in the spring of 1877 , not as a soldier but — thanks to a malady that "saved" him from military service - as a correspondent for the Moscow Gazette. The few weeks that he was attached to a regiment gave him time enough to witness some of the damage inflicted on "truth" by officialdom during the brief Russo-Turkish War. Letters from Kishinev and Bucharest, as well as from the border of Bulgaria, seem to reflect not only a distinct mix of stir and apprehension but also the beginning of a turn away from conservative ideas and toward more liberal inclinations.

The process of this conversion may be understood as accelerating just after Dostoevsky passed away (in February 1881), when Soloviev protested the death penalty for Tsar Alexander II's assassins. Moreover, his letters to Slavophile leaders in the first half of the 1880s evince a sharpening of arguments in defense of religious and ethical principle and against the dogma of Slavophile ideology. Taken collectively, these letters chart the weakening and increasing 
disarray of that ideology, which Soloviev would exploit in the ensuing years, eventually leading up to his taking the credit for having dealt a "mortal blow" to it.

Especially poignant in this regard are his letters to the editor Ivan S. Aksakov, who originally published Soloviev's “The Great Debate and Christian Politics" (1882-1884) serialized in the journal Rus'. These letters, written during the same period, first appeared in print only in 1913 and were likely withheld from earlier publication because of their withering criticisms of the Slavophiles' lack of principle as well as their dishonest methods and the crude deceptions conservatives perpetrated against him personally. Foremost among these criticisms was Soloviev's response to the unsubstantiated Slavophile charge that he had "turned Catholic," which more than coincidentally began to be circulated at about the same time that he came under police surveillance, with his passport even being confiscated at one point.

In his correspondence with Alexander A. Kireev, another Slavophile editor-but one with a conscience who, as it happened, shared a distrust of the clerical mindset-Soloviev analyzed conservative dogmatic obstacles to his core mission at the time: that is, the unity of the Eastern and Western churches. He began to expand on his thoughts about impediments such as the Eastern rejection of the filioque in the Nicene Creed and the Western assertion of papal infallibility.

Indeed, it could be said that Soloviev eventually became a liberal by default, in large measure as a result of the hostility with which conservatives-secular as well as clerical - met his demands for an honest assessment of Russia's overall attitudes toward the West. The decadence of the West may have been amply apparent, but it nonetheless possessed an energy that was lacking in an East suffering from oppressive reliance on stagnant tradition at the expense of progress and ukase at the expense of law.

Soloviev's attraction to that western energy strengthened in the 18861888 period. Evidence in his letters suggests that it was his extended stay in Austro-Hungarian Croatia in 1886 that opened wide both his heart and his eyes to fellow Slavs who lived under imperial political, economic, and social circumstances that were much freer than those of his homeland. Part of his stay in Croatia was dedicated to publishing the first volume of his History of Theocracy, which, however, would in the final analysis never make it to Russia. Upon returning from Croatia, he was greeted with scorn and even rejection, leading him to complain bitterly to another Slavophile editor, A. N. Aksakov, that it was now "impossible to publish anything" in Russia. It is at about the same 
time that Soloviev's letters begin to detail a deluge of disinformation and false witness against him, the purpose of which was apparently to discredit anything he might write. Not only would that campaign continue even after Russian censorship eased substantially in the waning years of the nineteenth century, but it virtually followed him to his grave and beyond, based as it was first and foremost on rumors and charges that he had abandoned Orthodoxy and/or had converted to Roman Catholicism.

Such rumors and charges cannot be substantiated or supported in his correspondence, which flatly contradicts them. Soloviev repeatedly gave testimony over the years, vigorously protesting what he called "slanderous accusations," and insisting that his life's calling did not include communion with Rome or entail convincing others to leave Orthodoxy for Catholicism. And he pointed out that the conveyers of such rumors and charges, even if they were Orthodox priests, did not have authority, in his words, to "excommunicate me from the church."

By the spring of 1887 clerical authorities had subjected Soloviev's History and Future of Theocracy (published abroad) to "total sequester" in Russia, an application of what he called the "blunt Greco-Russian fist." In great frustration he was forced to abandon this multivolume project on biblical righteousness, which he viewed as a kind of Christian political theory of the state - in his words, a "theocratic Leviathan"-based on what he called "free theocracy." (The project clarified the Hebrew Bible's representation of three distinct branches or offices: prophet, priest, and king.) Only much later would he indicate that he had wasted his "best years" on it.

Soloviev's transition from Slavophilism to liberalism-to which he adjoined himself at first "on practical grounds"- progressed substantially during this time of rejection. It was at this time that he explored the possibility of publishing his work with Mikhail M. Stasiulevich, editor of the decidedly liberal secular journal Messenger of Europe (Vestnik Evropy): and by 1891 Soloviev would consider himself an "employee" of that journal.

It was also during this time of transition that Soloviev's letters to friends began to detail how he was putting his efforts into a "little book" that would have to remain a "big secret"-perhaps because it was being prepared abroad with editorial assistance from two Russian Catholic priests in France, the Jesuit Fathers Pavel Pierling and Ivan Martynov. This association with Jesuit priests may have been a prime reason why slanderous rumors and stories about Soloviev expanded, especially after the big secret was published as the little French book that would make his name known throughout Europe-Russia and the 
Universal Church (La Russie et l'Église universelle, 1889). A running account of all the problems relating to the appearance of that work highlights his correspondence with Frs. Pierling and Martynov in that period.

The number and content of Soloviev's letters to Jesuits - whose "bad" reputation he had initially accepted sans critique in his youth - conveys the extent to which he relied on their good counsel at a critical point in the development and refinement of his publishing agenda in 1886-1888. Soloviev's correspondence with the Jesuit fathers illuminates his desire to mold his agenda to suit Western audiences and suggests how much he relied on Jesuit help for the initial reception of his ideas. Indeed, without the counsel and significant editorial assistance of Frs. Martynov and Pierling, it is difficult to see how that work could have taken shape at all, much less met with approval in France and across Europe.

There is some irony in the fact that Russia and the Universal Church proved to be a watershed in Russia as well as abroad, for this work brought the kind of attention and audiences that Soloviev could not have reasonably expected up to that time. By abandoning the cumbersome detailing of Old Testament law and ethics in favor of an elegant sketch of Russia's cultural and political failingsespecially regarding ethnic and religious reconciliation and its irrational rejection of Europe-he secured for himself a place in the pan-European intellectual pantheon.

Moreover, Soloviev's Jesuit correspondence may be seen as the beginning of his embrace of a "social" gospel, which would take shape more clearly in his societal and political commentary, as he addressed the religious, theological, and political strictures plaguing Russia. At a critical juncture in the long conception period of Russia and the Universal Church, Soloviev summarized in a letter what was to become that little book's first part:

(1) One has no reason to believe in a grand future for the people of Russia in the domain of purely human culture (social institutions, science, philosophy, arts and letters).

(2) The true orthodoxy of the Russian people possesses nothing special and will not separate us from the West.

(3) One does not find any positive element determining the religious future of Russia either in the official church or among dissidents.

(4) Russian caesaropapism is a principle of foreign origin and essentially anti-Christian.

(5) It is absolutely impossible to find or to believe that there is a center of unity and a guarantee of liberty for the Church in the East. 
Soloviev's inclination "to be just" toward Catholics and Catholicism had begun at least a decade earlier, in his "Lectures on Godmanhood" (or "Divine Humanity," 1877), in spite of his early Slavophile sentiments and his relationship to Dostoevsky, who had not only become famous in Russia for his prose fiction but also for his antisemitic, anti-Catholic, and, more specifically, zealously apocalyptic anti-Jesuit views. We learn from Soloviev's extensive correspondence with the Jesuit fathers how and why the young philosopher's "sympathies" had started to deepen and run counter to such views, moving in the direction of reconciliation even while Soloviev and Dostoevsky were exchanging ideas and associating rather closely in the late 1870s.

The spiritual and material elements of that reconciliation appear markedly in his letters beginning in the late 1880s, as his evangelistic fervor embraced East and West, Catholics and Orthodox, Christians and Jews, liberals and conservatives, and rich and poor, as well as Russians and Slavs themselves, both within and outside the empire. When Soloviev wrote about Russia and Europe, a painful note may be detected both in his use of terms and in his tone, because he believed Russia to be an integral part of Europe, not an alien adjunct or peripheral addendum. But the reality that confronted him was for the most part that of a predictable reactionary impulse on the part of Russian officialdom to keep separate from the West, seemingly at every turn.

Along these lines, Soloviev went to some length to point out the harmful direction that the thinker Nikolai Ya. Danilevsky had justified in his influential work Russia and Europe, a standard for Slavophiles and other conservatives who feared and despised Catholicism, Judaism, and the effects of Westernization more generally. Directly taking issue with Danilevsky many times in his correspondence of those years, Soloviev used that writer's work as a launching pad for his own early forays in the subject of national identity or "nationality"which he affirmed as a positive trait. But his underlying purpose in that discussion was to expose the anti-Christian roots of divisive "nationalism"-a negative phenomenon. Taking the extreme Slavophile-Orthodox version of nationalism to task, he would compare it to a plague of "syphilis," and refer to nationalists themselves as representing a "pseudopatriotic clique ... a grunting and howling embodiment of the national idea."

If one keeps all this in mind, the conclusion of a long draft essay (not included in this collection) carrying the title "The Sins of Russia" [Grekhi Rossii, 1887] becomes particularly instructive. Not surprisingly, it remained unpublished, surviving in rough form only in a letter to Soloviev's friend the young Jewish legal scholar and activist Faivel Bentsilovich Gets: 
\begin{tabular}{l|l} 
xxvi & Introduction: The Karamazov Correspondence
\end{tabular}

As long as a forcible system of Russification continues on the borders out of false considerations, as long as millions of Russian subjects are forcibly isolated from the rest of the people and subject to a new form of serfdom on the other side, and as long as a system of capital punishment hangs over religious conviction and a system of compulsory censorship over religious thought—Russia will remain morally unfree and spiritually paralyzed and will see nothing apart from failures in all its affairs.

Later, in a letter to M. M. Stasiulevich, Soloviev alluded to the contours of Russia's political-religious ailment on the occasion of the passing of Mikhail N. Katkov, another leading Slavophile reactionary voice who had claimed that Russia's "vital essence" lay in state control of religion: "Katkov repeated a thousand times that the basic advantage and vital essence of Russia consists in the absence of independent religious authority, through which the absolute monarchy of the state is secured. De facto, he was right, but wouldn't it be useful to show that from a Christian point of view this state monarchy is usurpation de jure?" It seems clear that Hebrew lessons from Faivel Gets beginning in the early 1880s helped accelerate what quickly blossomed into an unflinching lifelong conviction of the need for full and equal civil rights for Russia's Jews. Soloviev's activity on behalf of the Jewish minority's efforts to attain such rights earned this Christian the signal honor of a long posthumous entry in the BrokhausEfron Jewish Encyclopedia [Evreiskaia entsiklopedia Brokgauza-Efrona].

A number of letters in this collection add to our knowledge of Soloviev's activity on the part of the Jewish minority and against antisemitism in Russiaculminating in the famous protest he composed and circulated against the wave of pogroms in 1889-1890. Supported and signed by several dozen intellectuals that included L. N. Tolstoy, the collective effort eventually appeared in The Times of London in December 1890.

Publication of the London Times letter on antisemitism along with the appearance (at long last) of Soloviev's "little book" in France provided fodder for intensified and crude editorial attacks against him in clerical and conservative secular organs such as The Moscow Gazette (Moskovskiia vedomosti), The Church Messenger (Tserkovnyi vestnik), and The Citizen (Grazhdanin). The cloud of false claims about Soloviev's religious affiliation-along with fabrications about his personal life, overt misstatements, misquotations from and distortions of his work in these and other publications-did, however, prove to have a silver lining: they presented him with opportunities to "correct" his opponents, answering them at length in letters to editors. Readers of these 
publications were treated to the deftness of Russia's most brilliant polemicist, whose candor, sharp wit, and keen sense of language compelled them to take him seriously - and his opponents to take more care the next time they engaged him on the printed page.

It is in the context of this relentless campaign against Soloviev that the devastating famine of the early 1890 s set in, leaving an indelible imprint on perceptions of Russia's political and economic state of affairs both domestically and internationally. He complained directly and bitterly in his letters about the lack of response on the part of Russian authorities, expressing frustration over their unwillingness to permit any public discussion of the famine, much less to allow private associations to help feed the starving masses in order to mitigate its worst aspects. Prevented from publishing about the situation directly, he embedded thinly veiled references in various texts, as at the end of an article titled "Imaginary and Effective Measures for Lifting Public Well-being” (1892), where he suggested that a kind of moral "disease" had afflicted the body politic for a number of years and in a number of ways:

Let's picture for ourselves a kind man, healthy and strong, wise and sensible, clever and capable from birth — and everyone considers our Russia as precisely such a person, and justly so. We learn that this person, or nation, finds itself in an extremely sad condition: it's ill, ruined, demoralized. If we want to help it, we will certainly try first of all to find out what's the matter, why it is that it has fallen into such a pitiful situation.

The image proceeds on to false ideas-bordering on a grandiose and hostile "mania"-as being the cause of that illness, the sickly entity imagining "all its neighbors as enemies" posing "nonexistent dangers" that require readiness to "spend all its means and time" on defensive measures, even against internal foes. ${ }^{15}$ It has been suggested that Soloviev went even beyond such criticism, to the point of discussing with others overt opposition to the regime. ${ }^{16} \mathrm{~A}$ few of the letters from that period do appear cryptic in tone, but none that contain anything more than innuendo have survived - if in fact any such serious discussions ever took place.

However, two letters to Count L. N. Tolstoy do contain an intimation of another fascinating story tangentially related to the famine. In them Soloviev referred in passing to "Krauskopf," a name that gives access to a seldom-told tale in which Soloviev acted as kind of go-between in a US attempt to lend material assistance to Russia’s Jews. 
A Prussian-born American reformed rabbi and teacher named Joseph Krauskopf had helped assemble two shiploads of food relief during the 1891-1892 famine. In 1894 he tried to obtain permission to enter Russia to offer "the Czar a plan that might end or lessen the terrible persecution of the Jews in his realm." The plan, directly inspired by Tolstoy's pastoral ideas, essentially involved setting up self-sufficient agrarian communities somewhere in the interior of Russia.

As Krauskopf relates, after being denied a visa by Russian authorities because of his religion, he "conferred" with US President Grover Cleveland and his secretary of state. The latter then cabled the US consul to St. Petersburg, Andrew White, a scholar as well as a diplomat, who was instructed to obtain permission for Krauskopf from the foreign office there. White received the following peremptory reply: "Russian government deeply regrets its inability to accede to request in behalf of Reverend Jewish divine."

The matter somehow soon ended up on the floor of the US Congress, in which "a bill was introduced ... to the effect that the treaty between the two countries be declared abrogated if an American citizen be turned back from the gates of Russia by reason of his religion." That seemed to have solved Krauskopf's visa problem. But it was Soloviev who apparently had a hand in assisting White in facilitating Krauskopf's meeting with Count Tolstoy at his estate, Yasnaya Polyana. There the American rabbi and the Russian novelist eventually did have a lengthy meeting, which, of course, could never have led to any resettlement or self-government for Russian Jews but did inspire Krauskopf to set up agricultural schools in the United States. ${ }^{17}$

Interestingly, Tolstoy's written response to Soloviev concerning Rabbi Krauskopf contained a characteristically eccentric complaint, especially considering the letter's recipient. While sympathizing with Krauskopf's position, the count found the American to be of a "very un-Christian spirit," and he expressed repulsion at the rabbi's belief that "an eye for an eye" was preferable to "turning the other cheek." 18

Perhaps of more direct interest here is Rabbi Krauskopf's amusing (if inaccurate) recollection of the man who had anonymously assisted in easing his meeting with the literary and moral icon:

My first impression that I was classed with the other afflictions of the count's universal popularity soon wore off, however, by reasons of a letter to the family which I brought with me from a distinguished professor. This gentleman had, a short time before, been dismissed from the university of St. Petersburg because he had published an essay on The Ethics of the 
Talmud, in which he had endeavored to show the lofty moral teachings of the Jews. I had made his acquaintance while in St. Petersburg, and before leaving that city he called on me, and asked me whether I would not take a letter from him, of an entirely uncompromising nature, to Tolstoy, inasmuch, as at that particular time, a letter mailed to the count did not, for easily accountable reasons, always reach him. I readily consented, and that little service, the professor having been a great favorite of the count, made me a welcome guest also to the family. ${ }^{19}$

\section{ENTER THE DRAGON, AND EXIT SOLOVIEV}

Soloviev's stances on politics and human rights even found their way into his poetry at the end of his life, albeit in somewhat less than lucid fashion. His enigmatic and perhaps most misunderstood poem "The Dragon" (Drakon) concerning Germany and China-first appeared in a letter to M. M. Stasiulevich a few weeks before his death. Here is my unrhymed translation:

\section{The Dragon}

(To Siegfried)

From out of the invisible heavens

The dragon showed its brow-

And the approaching day followed

With a fog of irrefutable miseries.

Indeed, jubilations won't cease

Nor praises to eternal peace,

Careless laughter and exclamation:

"Life is good and there's no evil in it!"

Heir of the sword-bearing host!

You are faithful to the banner of the cross,

The fire of Christ is in your Damascus blade,

And menacing words are-holy.

God's bosom is full of love,

It calls us all alike ...

But before the dragon's trap

You conceived: the cross and sword-are one. ${ }^{20}$

It is true that Soloviev had elsewhere expressed criticism of Chinese culture as a historical fount of materialist philosophy; and he had portrayed in his "Brief 
xxx $\mid$ Introduction: The Karamazov Correspondence

Tale about the Antichrist" a future revanchist China that, by allying with Japan, overwhelms Europe and Russia prior to the arrival of a Nietzschean "man of the future" who restores hope and order while attempting to transcend both secular and moral law at the "end of history."

But "The Dragon" must be read in context both of this "end times" sense and of the actual historical details surrounding it. The poem carries the date 24 June 1900, a few days after Kaiser Wilhelm of Germany - the "Siegfried" to whom the poem is ostensibly dedicated-sent a regiment to support other European troops in their infamous and bloody pacification of Chinese resistance to Western imperialism. When read alongside Soloviev's poem "Pan-Mongolism" (dated 1899), the dragon poem reflects Soloviev's long-standing pessimism and deepening despondency concerning declining Christian norms across Europe (including Russia) in favor of pagan, materialistic values. ${ }^{22}$ Russia was to pay a high price, as the last lines of "Pan-Mongolism" suggest:

And scraps of your banners are given

for amusement to the yellow children.

He who could forget the testament of love

Will resign himself in trembling and terror,

And the Third Rome lies in the dust.

And now there will not be a Fourth.

The first four lines of "Pan-Mongolism" were actually penned in October 1894, appearing in a letter sent from Finland to M. M. Stasiulevich dated April 1895. In that letter Soloviev satirically congratulated himself, Stasiulevich, and another friend "on the conclusion of an alliance between Japan and China," referring indirectly to the Treaty of Shimonosaki of 1895, which ended the very brief Sino-Japanese War-a fact that no doubt helped in forming part of the later Antichrist story's plot.

However, Germany-with the help of France and Russia-sought to replace Japan as the arbiter of China's destiny. Moreover, Kaiser Wilhelm (who is credited with coining the racist phrase "yellow peril" [gelbe Gefahr]) also just happened to be a rabid antisemite and, as Soloviev had warned long before, the poisonous antisemitic press in Germany and Austria had been spreading its messages throughout Russia, a fact that spurred the Russian theologianpoet on in his defense of the Jewish nation. ${ }^{23}$ Therefore, Soloviev could not have understood the German Kaiser as a good and moral Christian ruler, as the standard-bearer of a truly "Christian” kingdom. And in the context of Soloviev's 
article "China and Europe," written ten years earlier, Europeans had no business at all exploiting and doing battle with China, for such behavior would not solve the West's own intrinsic and problematic materialism. ${ }^{24}$

According to Sergei Trubetskoy, who attended Soloviev's deathbed, the two old friends discussed the paucity and inadequacy of European diplomacy toward the East, with the Western empires simply proposing to engorge themselves materially by partitioning China. Soloviev's last observations on the matter implied a rejection of European response to the tumultuous Boxer Rebellion in 1900, that such machinations were bound to fail: "And what's the moral baggage that the European nations are going to battle China with! Not Christianity, no ideas other than those of the Trojan War's epoch.”

Trubetskoy also related that the two then returned to the topic of the "dragon" with reference to Kaiser Wilhelm's frightful incitement of the troops being dispatched in early July. Soloviev clarified the meaning of the poem as reflecting the onset of the "end times." Just as significantly, as Soloviev faded away, he asked Trubetskoy's wife to prevent him from going to sleep because he "had to pray for the Jewish nation" as he read the Psalms to himself in Hebrew, clearly fearful about what might be in store for the people. ${ }^{25}$

\section{TECHNICAL MATTERS: ASSEMBLY, CHRONOLOGICAL RECONSTRUCTION, TRANSLATION, SOURCES}

This book represents the first translated and annotated assemblage of Vladimir S. Soloviev's essential correspondence in a coherent chronological order. I took on this project fully understanding that the letters themselves had to be reimagined and rearranged to achieve a narrative effect that would do justice to their writer.

E. L. Radlov faced the problem of consolidating and assembling Soloviev's letters without knowing how many he would ultimately receive; they kept coming to him from a variety of sources. By the publication of the first volume (1908), he seemed to think that two volumes would be the result, with a second to contain many that had already been published in one or another journal. ${ }^{26}$ With the publication of that second volume (1909) a third was deemed necessary to accommodate these, but Radlov remarked that even that would be "far from all the letters of Vl. Soloviev," suggesting that "the most important ones" might be forthcoming in a distant future. That final (fourth) volume turned out to be after the Bolshevik Revolution, including some letters that may have been intentionally withheld from the first three due to religious and political sensitivities. 
Perhaps in haste, Radlov did not attempt to organize the letters on a strict chronological basis within each volume, but only separately, according to the name of each correspondent. Many lacked a precise date, while others turned out to have been misdated. Understandably, this arrangement proved less than optimal. In his introduction to the third volume, Radlov did acknowledge that a small number of letters required chronological reconstruction, and he affirmed that an index of some kind would have been helpful to readers of the first three volumes, but all he was able to do was provide an index of personal names for the fourth.

Separated by more than a century from the people and events of that time, contemporary readers are faced with another equally challenging problem in these volumes-Radlov supplied almost no historical notes and only scant biographical information for a very few of Soloviev's correspondents; neither did he think it necessary to identify for his readers the many other people and events cited or alluded to in passing by Soloviev. The lack of such essential features substantially clouds the modern reader's ability to appreciate them in context (even for those encountering Soloviev in the original Russian).

I have addressed these several matters as follows.

First, many more than just the few letters Radlov mentioned turned out to be misdated. After some effort, I was able to situate a lot of these misdated letters-along with many others that remained undated-more precisely and then to reorganize these letters strictly on the basis of chronology (dispensing completely with the "individual correspondent" organizational principle), beginning with the very first (from 1871) and continuing through to the end of Soloviev's life (1900). Annual variations in the volume of surviving correspondence suggested its arrangement, either grouped over several years (1871$1873 ; 1874-1876)$ or by single year $(1886 ; 1887)$.

The overall effect, I believe, is much more organic, in that the reader is able to follow the same topics and concerns that absorbed and inspired Soloviev chronologically over the course of days, weeks, months, or even years, in a much more lively and compelling manner than in the original form in which these letters first appeared in print, scattered as they were over many different publications and then assembled somewhat idiosyncratically over four volumes, published separately over the course of more than a decade.

Since Soloviev left no autobiography, these letters, reorganized in this way, have for his readers a "biographical significance" lacking in his books and essays, perhaps even supplying what is the most reliable narrative available to us, not only covering the thirty years of his life for which letters exist but also 
providing personal reflections on his younger days. ${ }^{27}$ Apart from several posthumous biographical essays by Soloviev's friends, the several attempts at booklength biographies of Soloviev exhibit inaccuracies and speculative judgments often based on personal loyalties and/or rumor, which tend to undermine their overall quality and reliability. Conversely, his letters offer a consistently frank diary-like account, which illuminates his thought world as it developed over the course of his adult life. To reiterate, my translations give English reading audiences for the first time an intimate view into the evolution of ideas that moved him, as well as private glimpses into his humor, pathos, and poetic imagination.

Significantly, Soloviev's letters became a testing ground for drafts of various poems, both serious and humorous (including some not in any collection at all). Almost all of Soloviev's poetry was written in rhyming verse, which does not often translate well into English. I have attempted whenever possible to produce a suitable rhyme scheme for his humorous verses, where rhythm and rhyme might make more sense in English, but I have avoided doing so with the more serious poems. Transliterations in my notes are intended for Slavicists, linguists, or translators concerned with poetic cadence, rhyme, and sonority.

Wherever appropriate, I have used square brackets for brief clarifications and translations of foreign words and phrases that arise intermittently in the Russian text, both prosaic and poetic.

I have also supplied a general index and added an index of biblical references. Soloviev's biblical citations and allusions at times appear in an older Slavonic form and at times in more modern Russian; I have replaced them wherever possible with King James English, which I think better suits the nature of the texts.

There are two appendixes: one presents eyewitness testimony regarding Soloviev's final days; another contains brief biographical information on each of his correspondents in hopes of adding a more fluid context for those less familiar with the wide range of people with whom Soloviev exchanged letters.

My annotations add relevant information about people, places, and events mentioned in passing or alluded to indirectly in the letters. They appear in consecutively numbered endnotes for each year or group of years, separately from the explanatory footnotes that Soloviev himself at times appended to his letters, along with a number of footnotes added by Radlov and/or Soloviev's correspondents. (In the latter case, I have indicated their origins by use of $E d$. note or a given correspondent's initials.) My aim here is to help blend Soloviev's public and personal personas into a single entity, an effort that I believe affords the reader a more holistic view of the moral philosopher's thinking and behaviorbad as well as good-from various aspects. 
xxxiv | Introduction: The Karamazov Correspondence

This volume contains more than three hundred letters, notes, and telegrams that originally appeared either in the first editions of his published letters and/or in journals and newspapers prior to 1917. Whenever possible, I made use of the first published version. (Discrepancies sometimes mark reprinted versions.) Four criteria governed my decisions to exclude many more letters from this collection: (1) mundaneness and/or brevity-those of one, two, or three lines: brief felicitations, dinner invitations, appointment times, receipts of payment, requests for loans, and so on, adding little or no substance to the biographical narrative, of little or no interest to the general reader; (2) those whose purpose was primarily, if not exclusively, the technical editing of works other than his own, and/or "Dictionary" business; (3) the lack of a date-those without significant new information whose dates could not be determined or even reasonably approximated, even after research; and (4) repetition of content-those replicating information to another individual or other individuals, composed at about the same time. For letters excluded on the basis of criterion no. 4, priority was given either on the basis of date, the existence of significantly important additional material content, or more substantive general "fit" into the biographical narrative. In these instances I have tried to furnish information regarding what has been excluded wherever relevant.

A few words are in order about some other minor editorial choices as well as my sources.

A number of abbreviations appear in this book with varying degrees of frequency. Some occur only rarely or intermittently, particularly those referring to calendar dating and languages:

O.S.: "Old Style," Gregorian calender, reflecting a difference of thirteen days. Croat.: Croatian; Eng.: English; Fr.: French; Ger.: German; Gk.: Greek; Heb.: Hebrew; Ital.: Italian; Rus.: Russian.

Those representing full titles of major sources tend to occur with greater frequency:

\section{Collected Works}

IRANS: From the Manuscripts of Anna Nikolaevna Schmidt, with letters to her from Vl. Soloviev (Iz rukopisei Anny Nikolaevny Shmidt, s pis 'mami knei Vl. Solov'eva [Moscow: 1916]). 
MMSp: M. M. Stasliulevich and His Contemporaries in Correspondence, vol. 5 (M. M. Stasiulevich i ego sovremenniki v ikh perepiske, t. 5 [St. Petersburg, 1913])

PVSS: Letters of V. S. Soloviev, 3 vols. (Pis'ma Vladimira Sergeevicha Solov'eva, 3 t. [St. Petersburg, 1908-1911])

PVSSkb: Letters of V. S. Soloviev to his brother Mikhail ("Pis'ma Vladimira Solov'eva k bratu Mikhailu," Bogoslovnyi vestnik [1915/1916])

SsVSS: Collected Works of V. S. Soloviev (Sobranie sochinenii Vladimira Sergeevicha Solov'eva [St. Petersburg: Obshchestvenaia pol'za, 19011903])

VSP: Vl. Soloviev, Letters (Vl. Solov'ev, pis'ma, ed. E. L. Radlov [Petersburg: Vremia, 1923])

\section{Journals, Newspapers, and Encyclopedias}

The Brokhaus-Efron Encyclopedic Dictionary (Entsiklopedicheskii slovar' F. A. Brokgauza i I. A. Efrona [St. Petersburg, 1890-1907])

The Brokhaus-Efron Jewish Encyclopedia (Evreiskaia entsiklopedia BrokgauzaEfrona [St. Petersburg: 1908-1913])

The Citizen (Grazhdanin)

Journal of the Ministry of Public Education (Zhurnal Ministerstva narodnago prosveshcheniia)

Messenger of Europe (Vestnik Evropy)

Moscow Gazette (Moskovskie vedomosti)

The News (Novosti)

New Times (Novoe vremia)

Problems of Philosophy and Psychology (Voprosy filosofii i psikhologii)

Russian Messenger (Russkii vestnik)

Russian Review (Russkoe obozrenie)

Russian Thought (Russkaia mysl')

Transactions (Transactions of the Petersburg Slavic Society [Izvestiia Peterburgskago Slavianskago Obshchestva])

Voice of Moscow (Golos Moskvy)

The Week (Nedelia)

Finally, a few comments are in order about matters such as formal titles of address, anachronisms, spelling, and diacritics. I have followed Soloviev whenever he abbreviated the Russian titles of prince or princess (kniaz', kniaginia) 
with "Pr." (Rus. kn.) and of countess and count (grafinia, graf) with "Ct." (Rus. gr.), but I have replaced many cumbersome, anachronistic salutations and formalities of address as the print originals have them (opting simply for "dear" or "my dear"), retaining such in only a few cases (e.g., letters to the tsar and to ecclesiastic personages). I have also dispensed completely with capitalization in other customary usages that might distract the reader (e.g., the formal second-person plural pronoun in various declensions: "You" "Yours" $[V y$, Vash]). I have otherwise kept to the text of the print originals and to their layout as much as possible. ${ }^{28}$ So I have retained all italics as they first appeared in print, as well as infrequently occurring diacritical marks in languages other than English (French, German, Greek, Croatian, Swedish). My overall intent has been to approximate the original feel of the letters in print for a modern English reading audience, without obscuring the sense of things. Along these lines my transliteration from the Cyrillic for the most part follows the Library of Congress system, with some adjustments, specifically with respect to commonly used spelling of names (e.g., Dostoevsky, Tolstoy). 